\title{
Factors affecting the cryosurvival of mouse two-cell embryos
}

\author{
J. K. Critser*\$§, B. W. Arneson*, D. V. Aaker $\dagger$, A. R. Huse-Benda* and \\ G. D. Ball* $+\ddagger$ \\ Departments of ${ }^{*}$ Laboratory Medicine, $\nmid$ Obstetrics and Gynecology, and $\ddagger$ Biochemistry and \\ Molecular Biology, Mayo Clinic and Mayo Foundation, Rochester, Minnesota 55905, U.S.A.
}

\begin{abstract}
Summary. A series of 4 experiments was conducted to examine factors affecting the survival of frozen-thawed 2-cell mouse embryos. Rapid addition of 1.5 M-DMSO $\left(20 \mathrm{~min}\right.$ equilibration at $25^{\circ} \mathrm{C}$ ) and immediate, rapid removal using $0.5 \mathrm{M}$-sucrose did not alter the frequency (mean \pm s.e.m.) of blastocyst development in vitro when compared to untreated controls $(90 \cdot 5 \pm 2.7 \%$ vs $95 \cdot 3 \pm 2 \cdot 8 \%)$. There was an interaction between the temperature at which slow cooling was terminated and thawing rate. Termination of slow cooling $\left(-0.3^{\circ} \mathrm{C} / \mathrm{min}\right)$ at $-40^{\circ} \mathrm{C}$ with subsequent rapid thawing $\left(\sim 1500^{\circ} \mathrm{C} / \mathrm{min}\right)$ resulted in a lower frequency of blastocyst development than did termination of slow cooling at $-80^{\circ} \mathrm{C}$ with subsequent slow thawing $\left(+8^{\circ} \mathrm{C} / \mathrm{min}\right)$ $(36 \cdot 8 \pm 5 \cdot 6 \%$ vs $63 \cdot 9 \pm 5 \cdot 7 \%)$. When slow cooling was terminated between -40 and $-60^{\circ} \mathrm{C}$, higher survival rates were achieved with rapid thawing. When slow cooling was terminated below $-60^{\circ} \mathrm{C}$, higher survival rates were obtained with slow thawing rates. In these comparisons absolute survival rates were highest among embryos cooled below $-60^{\circ} \mathrm{C}$ and thawed slowly. However, when slow cooling was terminated at $-32^{\circ} \mathrm{C}$, with subsequent rapid warming, survival rates were not different from those obtained when embryos were cooled to $-80^{\circ} \mathrm{C}$ and thawed slowly $(52.4 \pm 9 \cdot 5 \%$, $59 \cdot 5 \pm 8 \cdot 6 \%$ ). These results suggest that optimal cryosurvival rates may be obtained from 2-cell mouse embryos by a rapid or slow thawing procedure, as has been found for mouse preimplantation embryos at later stages. However, for the 2-cell stage, to achieve high survival rates with rapid thawing the temperature at which slow cooling is terminated is greater $\left(\sim-32^{\circ} \mathrm{C}\right)$ than values reported for later stages.
\end{abstract}

Keywords: mouse; 2-cell embryos; freezing rate; thawing rate; development to blastocysts

\section{Introduction}

Preimplantation mouse embryos of all stages from the 1-cell to the blastocyst stage are able to survive freezing to $-196^{\circ} \mathrm{C}$ and subsequent warming (see reviews by Whittingham, 1975; Maurer, 1976). However, optimal methods for freezing and thawing differ among embryos at different stages (Schneider \& Maurer, 1983; Massip et al., 1984a). While a great deal of information has been generated regarding factors affecting cryosurvival of mouse embryos at the 8-cell stage or later, relatively little is known about optimal freezing and thawing methods for earlier stages. Low temperature storage of later stage embryos works well for several mammalian species and has many practical applications (Whittingham, 1974; Whittingham \& Whitten, 1974; Seidel \& Seidel, 1981; Leibo, 1986). However, with increasing interest in basic research and applied techniques utilizing early cleavage stage embryos (e.g. in-vitro fertilization, nuclear transfer, gene injection) it is important to develop a more complete understanding of optimized cryopreservation procedures for

\$Present address: Center for Reproduction and Transplantation Immunology, Methodist Hospital, Indianapolis, IN 46202, U.S.A. 
1- and 2-cell mammalian embryos. Optimizing cryopreservation procedures may increase overall efficiency rates as in-vitro culture time, which has been shown to be negatively correlated with development in vivo (Bowman \& McLaren, 1970a, b; Hahn \& Schneider, 1982; Hoppe \& Coman, 1983; Massip et al., 1984b), could be eliminated or greatly reduced.

The objectives of this study were to examine the effects of (1) addition and removal of DMSO, and (2) the temperature at which slow cooling is terminated and subsequent thaw rate, on 2-cell mouse embryos.

\section{Materials and Methods}

Source of embryos. Female $\mathrm{B}_{6} \mathrm{D}_{2} \mathrm{~F}_{1}$ mice (Jackson Laboratories, Bar Harbor, ME, U.S.A.), aged 6-8 weeks, were maintained on a $14 \mathrm{~h}$ light: $10 \mathrm{~h}$ dark cycle. Females were induced to superovulate with a modification of a protocol previously reported (Whittingham et al., 1972). Each female was injected with 5-7 i.u. PMSG (Organon Pharmaceuticals, West Orange, NJ, U.S.A.) intraperitoneally, followed by i.p. administration of 5-7i.u. hCG (Organon) approximately $48 \mathrm{~h}$ later. The females were paired with adult ICR males (Harlan Sprague-Dawley, Madison, WI, U.S.A.) immediately after administration of hCG and checked for evidence of mating (presence of vaginal plugs) the following morning. Mated females were killed about $40 \mathrm{~h}$ after administration of hCG, and 2-cell embryos were flushed from the excised oviducts in a Hepes-buffered modified Tyrode's medium (TALP-Hepes) (Bavister et al., 1983) containing $3 \mathrm{mg}$ bovine serum albumin $/ \mathrm{ml}$ (BSA; Fraction V). All medium components, for this and other media used in these experiments, were obtained from Sigma Chemical Co., St Louis, MO, U.S.A., unless stated otherwise. The water used to prepare media was from a Milli-Q reagent water system (Millipore, Continental Water Systems, El Paso, TX, U.S.A.). Embryos were pooled across females, washed in fresh TALP.Hepes medium, and randomly assigned to treatments.

Freezing. Embryos were frozen by modifying the technique previously described by Whittingham et al. (1972). Embryos were placed directly into TALP-Hepes medium containing $1.5 \mathrm{M}$-dimethylsulphoxide (DMSO) and $20 \%$ fetal bovine serum (FBS) (GIBCO, Grand Island, NY, U.S.A.). Embryos were pipetted into 0.50 ml plastic straws which were heat sealed and allowed to equilibrate with the DMSO for 20 min at room temperature. Straws were placed vertically in the chamber of a programmable biological freezer (Model R204, Planer Products Ltd, Middlesex, U.K.) and (1) cooled at $3^{\circ} \mathrm{C} / \mathrm{min}$ to $-5^{\circ} \mathrm{C}$, (2) manually seeded and held at $-5^{\circ} \mathrm{C}$ for $10 \mathrm{~min},(3)$ cooled at $0 \cdot 3^{\circ} \mathrm{C} / \mathrm{min}$ to temperatures between -30.0 and $-80.0^{\circ} \mathrm{C}$ (see experimental designs below), and (4) placed directly into liquid nitrogen (liquid $\left.\mathrm{N}_{2}\right)\left(-196^{\circ} \mathrm{C}\right)$.

Thawing. Embryos were stored in liquid $\mathrm{N}_{2}$ for $15-30 \mathrm{~min}$, then thawed at $+8 \cdot 0^{\circ} \mathrm{C} / \mathrm{min}$ to room temperature (slow thaw) in the programmable freezer or in a $35-37^{\circ} \mathrm{C}$ water bath (rapid thaw). Immediately upon thawing, the contents of the straws were emptied into an organ culture dish (Falcon, Becton Dickinson Co., Oxnard, CA, U.S.A.) containing TALP-Hepes medium, $20 \% \mathrm{FBS}$, and $0.5 \mathrm{M}$-sucrose at room temperature for $10 \mathrm{~min}$, and the DMSO removed in a single step as previously proposed (Leibo \& Mazur, 1978; Schneider \& Mazur, 1984) and described for mouse embryos (Merry et al., 1983; Renard \& Babinet, 1984). The embryos were transferred to TALP (bicarbonate-buffered medium; Bavister et al., 1983) medium and placed in culture.

Assessment of embryo viability. Embryos were evaluated by light-microscopy immediately after the removal of DMSO and scored as viable or not viable on the basis of morphological criteria (Exp. 2 only). Embryos judged to be viable had (1) intact zonae pellucidae and (2) both blastomeres with non-granular cytoplasm and intact, distinct vitelline membranes. All recovered embryos were then placed into in-vitro culture in TALP medium (Bavister et al., 1983) at $37^{\circ} \mathrm{C}$ under $5 \% \mathrm{CO}_{2}, 95 \%$ air and high humidity. The 2-cell embryos were cultured for $72 \mathrm{~h}$ and development to the blastocyst stage, used as the end point for each experiment, was assessed.

Statistical analysis. All data from the experiments consisted of frequency data which were analysed by a weighted analysis of variance approach using percentage values after an arcsine transformation. Weighted values were equal to $1 / n$ and percentage values equal to 0 or 100 were replaced by $1 /(4 \times n)$ or $(n-1 / 4 n)$, respectively (where $n=$ the total number of observations) (Snedecor \& Cochran, 1982). The analyses were performed using the General Linear Models program of the Statistical Analysis System (Spector et al., 1985). A protected LSD was used for comparisons among treatments when appropriate (Steel \& Torrie, 1960).

\section{Results}

\section{Experiment 1}

Methods. This experiment was designed to evaluate the potential loss of embryo survival due to addition and removal of DMSO. Two-cell mouse embryos, 14-41 in each of 5 replicates, were randomly assigned to one of two treatment groups: (1) untreated controls or (2) embryos to which 
Table 1. Effect of freezing protocol on percentage recovery, viability and development to blastocyst stage of frozen-thawed 2-cell mouse embryos

\begin{tabular}{|c|c|c|c|c|}
\hline Treatment group & $\begin{array}{l}\text { Total no. of } \\
\text { embryos }\end{array}$ & $\%$ Recovery $\dagger$ & \% Viability & $\%$ Development $\$$ \\
\hline $\begin{array}{l}1 \text { (cooled to }-40^{\circ} \mathrm{C}, \\
\text { rapid thaw) }\end{array}$ & 111 & $82 \cdot 6 \pm 5 \cdot 6^{*}$ & $54 \cdot 0 \pm 5 \cdot 0^{*}$ & $36.8 \pm 5 \cdot 6^{*}$ \\
\hline $\begin{array}{l}2 \text { (cooled to }-80^{\circ} \mathrm{C}, \\
\text { slow thaw) }\end{array}$ & 112 & $94 \cdot 3 \pm 2 \cdot 6$ & $75 \cdot 3 \pm 4 \cdot 4$ & $63.9 \pm 5.7$ \\
\hline
\end{tabular}

Values are means \pm s.e.m., based on frequency data averaged over 10 replicates $(1441$ embryos/treatment).

$\uparrow$ No. recovered/total no. of embryos frozen.

$\$$ No. viable/total no. of embryos frozen.

$\S$ No. of blastocysts/total no. of embryos frozen.

${ }^{*} P<0.05$ compared with Group 2 value.

DMSO was added and removed as described above. Embryos were exposed to treatments in $0.50 \mathrm{ml}$ plastic straws to simulate a prefreeze situation.

Results. Neither recovery of embryos from the plastic straws nor development of 2-cell embryos to the blastocyst stage in vitro differed between the untreated control group $(n=111)$ and the group to which DMSO was added and removed $(n=238),(P>0.10)(100.0 \pm 0.0$ vs $97.3 \pm 1.6 \%$ and $95 \cdot 3 \pm 2 \cdot 8$ vs $90 \cdot 5 \pm 2 \cdot 7 \%$, respectively).

\section{Experiment 2}

Methods. This experiment was designed to test the hypothesis that terminating slow cooling at $-40^{\circ} \mathrm{C}$ with subsequent rapid thawing or terminating slow cooling at $-80^{\circ} \mathrm{C}$ with subsequent slow thawing would produce similar survival rates of frozen--thawed 2-cell embryos, comparable to those reported for 8-cell mouse embryos (Whittingham et al., 1979). Two-cell embryos were randomly assigned to one of two treatment groups (1) slowly cooled from -5 to $-40^{\circ} \mathrm{C}$, plunged into liquid $\mathrm{N}_{2}$ and rapidly thawed, or (2) slowly cooled from -5 to $-80^{\circ} \mathrm{C}$, plunged into liquid $\mathrm{N}_{2}$ and slowly thawed. The numbers of embryos recovered and, the numbers of viable embryos immediately after thawing and development to the blastocyst stage were used as end points.

Results. As shown in Table 1, recovery rates, viability, as estimated by morphological integrity after thawing, and development to the blastocyst stage in vitro were all significantly lower in Group 1 than Group 2.

\section{Experiment 3}

Methods. This experiment was designed to examine the proposed interaction between the temperature at which slow cooling is terminated and thawing rate and consisted of two separate studies. The first (3a) was a $2 \times 2$ factorial design ( 2 levels of temperature at which slow cooling was terminated and 2 levels of thawing rate). The 20-28 2-cell embryos in each of 5 replicates were randomly assigned to 1 of 4 treatment groups: (1) slowly cooled from -5 to $-40^{\circ} \mathrm{C}$ with subsequent rapid thawing; (2) slowly cooled from -5 to $-40^{\circ} \mathrm{C}$ with subsequent slow thawing, (3) slow cooling from -5 to $-80^{\circ} \mathrm{C}$ with subsequent rapid thawing, or (4) slow cooling from -5 to $-80^{\circ} \mathrm{C}$ with subsequent slow thawing. Study $3(\mathrm{~b})$ was a $2 \times 6$ factorial design ( 2 levels of thawing rate, rapid or slow; 6 levels of temperature at which slow cooling was terminated, $-30,-40,-50$, $-60,-70$ or $-80^{\circ} \mathrm{C}$ ) to examine this interaction further. Two-cell embryos were randomly assigned to 1 of the 12 treatment groups formed by this design.

Results. In Exp. 3(a) there was a significant interaction $(P<0.05)$ between the temperature at which slow cooling was terminated and the rate of thawing. When embryos were cooled to $-40^{\circ} \mathrm{C}$, 


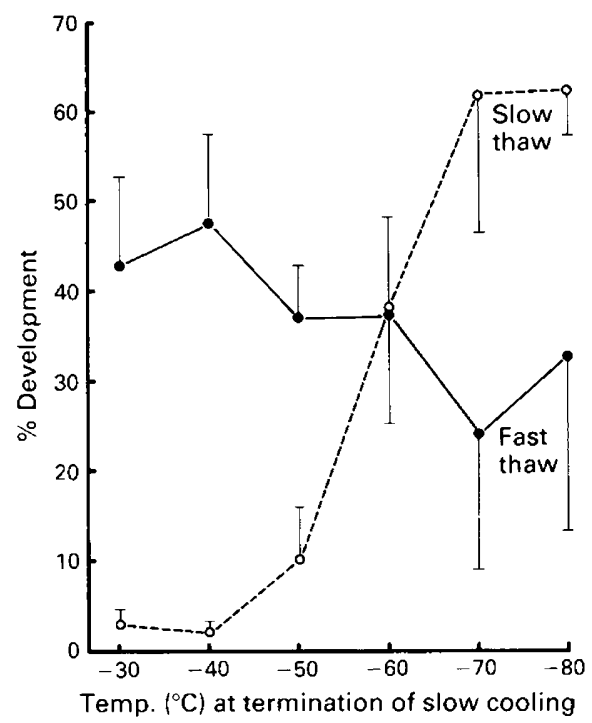

Fig. 1. Percentage (total no. of blastocysts/total no. of embryos frozen) development to the blastocyst stage at $72 \mathrm{~h}$ after thawing. In each of the 3 replicates, 20-23 embryos per treatment were used ( 63 embryos per treatment). Values are mean \pm s.e.m. based on frequency data averaged over the 3 replicates.

survival was higher $(42.5 \pm 7 \cdot 0 \%$ ) with rapid thawing (Group 1) than with slow thawing $(2 \cdot 0 \pm 2 \cdot 0 \%$, Group 2$)$. However, when embryos were cooled to $-80^{\circ} \mathrm{C}$, survival was higher with slow thawing $(53.7 \pm 8 \cdot 5 \%$, Group 4$)$ than with rapid thawing $(12.6 \pm 4 \cdot 2 \%$, Group 3$)$. Recovery rates ranged between 83.6 and $88.0 \%$. There was a main effect $(P<0.05)$ of temperature at which slow cooling was terminated, with fewer embryos cooled to $-40^{\circ} \mathrm{C}$ developing to the blastocyst stage than embryos cooled to $-80^{\circ} \mathrm{C}(22 \cdot 2 \pm 7 \cdot 6 \%$ in Groups $1+2$ and $33 \cdot 1 \pm 8 \cdot 2 \%$ in Groups $3+4)$. Overall, there was no difference in the frequency of blastocyst development between embryos thawed rapidly $(27 \cdot 5 \pm 6 \cdot 3 \%$ in Groups $1+3)$ or slowly $(27 \cdot 8 \pm 9 \cdot 5 \%$ in Groups $2+4)$. The results of Exp. 3(b) are presented in Fig. 1. As for Exp. 3(a), there was a temperature at which slow cooling was terminated by thaw-rate interaction $(P<0.05)$. When cooling was terminated above $-60^{\circ} \mathrm{C}$, survival was enhanced with subsequent rapid thawing. However, when cooling was terminated below $-60^{\circ} \mathrm{C}$ higher survival was observed with subsequent slow thawing. Recovery rates ranged between 82.5 and $96.8 \%$. There was neither a temperature at which slow cooling was terminated nor a thaw-rate main effect $(P>0 \cdot 10)$.

\section{Experiment 4}

Methods. This experiment was conducted to test the hypothesis that terminating slow cooling at temperatures between -32 and $-40^{\circ} \mathrm{C}$ with subsequent rapid warming would provide optimal survival rates similar to embryos slowly cooled to $-80^{\circ} \mathrm{C}$ and thawed slowly. Two-cell mouse embryos were randomly assigned to 1 of 7 treatment groups: (1) untreated controls, (2) cooled to $-80^{\circ} \mathrm{C}$ and thawed slowly, or rapidly thawed after cooling to (3) $-32^{\circ} \mathrm{C}$, (4) $-34^{\circ} \mathrm{C},(5)-36^{\circ} \mathrm{C}$, (6) $-38^{\circ} \mathrm{C}$ or $(7)-40^{\circ} \mathrm{C}$.

Results. There was a significant main effect of treatment $(P<0.05)$. The frequency of embryo survival (development to the blastocyst stage) was not different $(P>0 \cdot 10)$ between the groups cooled to $-32^{\circ} \mathrm{C}$ and thawed rapidly or to $-80^{\circ} \mathrm{C}$ and cooled slowly $(52.4 \pm 9 \cdot 5 \%$ in Group 3 and $59.5 \pm 8.6 \%$ in Group 2). A greater frequency $(P<0.05)$ of embryos survived cryopreservation in Groups 2 and 3 than in all other treatment groups: Group 4, 26.2 $\pm 9 \cdot 5 \%$; Group 5, $11.9 \pm 2 \cdot 4 \%$; 
Group 6, 26.2 $\pm 6 \cdot 3 \%$; Group 7, 23.8 $\pm 4 \cdot 8 \%$. Values for embryos in Groups $2-7$ had a lower $(P<0.05)$ frequency of survival than did those in Group 1 (untreated controls, $81.0 \pm 5 \cdot 7 \%$ ). Recovery rates ranged between $85 \cdot 7$ and $95.2 \%$.

\section{Discussion}

The use of cryoprotectants is essential to obtain survival after mammalian embryos are cooled below $-20^{\circ} \mathrm{C}$ (Schneider \& Mazur, 1984). The results of Exp. 1 of the present study indicate that a single-step addition of $1.5 \mathrm{M}$-DMSO combined with its removal in $0.5 \mathrm{M}$-sucrose does not affect the development of 2-cell mouse embryos to the blastocyst stage. These results are in basic agreement with the generally held view that DMSO and sucrose in concentrations needed for cryoprotection are not toxic to mammalian embryos (Schneider \& Mazur, 1984). However, these data are in apparent disagreement with the early report by Whittingham \& Wales (1969) which suggested that $16 \%$ DMSO might be toxic to 2-cell mouse embryos. These differences may be due to the fact that the present study utilized a lower concentration of DMSO $(1.5 \mathrm{M}, \sim 11 \%)$. These data support the use of $1.5 \mathrm{M}$-DMSO for the 2-cell stage and are important in the context of examining factors which affect a specific developmental stage since each stage may vary in susceptibility to cryoprotectant concentrations and their rates of addition and removal (Schneider, 1986).

Initial reports investigating the effects of cooling and thawing rates on the survival of mammalian embryos indicated that slow cooling $\left(\leqslant 1^{\circ} \mathrm{C} / \mathrm{min}\right)$ to $-60^{\circ} \mathrm{C}$ or below with slow warming $\left(4-25^{\circ} \mathrm{C} /\right.$ min) resulted in a higher frequency of survival than with rapid warming $\left(\sim 250 \sim 1500^{\circ} \mathrm{C} / \mathrm{min}\right.$ ) (see Polge \& Willadsen, 1978; Whittingham et al., 1979; Rall \& Polge, 1984). However, early reports examining factors affecting the cryosurvival of cattle and sheep embryos indicated that relatively high survival rates could be obtained with rapid warming rates if slow cooling was terminated between -30 and $-45^{\circ} \mathrm{C}$ (Willadsen, 1977; Willadsen et al., 1978; Polge \& Willadsen, 1978). Subsequently, Whittingham et al. (1979), using mouse 8-cell embryos equilibrated with $1.5 \mathrm{M}-$ DMSO at $0^{\circ} \mathrm{C}$ and frozen in glass test-tubes, critically tested the hypothesis that an interaction exists between the temperature at which slow cooling is terminated and thaw rate. The results of their experiment demonstrated that such an interaction does indeed exist and suggested that embryos survive rapid or slow thawing equally well if slow cooling is terminated between -35 and $-40^{\circ} \mathrm{C}$ (maximum survival at $\sim-40^{\circ} \mathrm{C}$ ) and at or below $-60^{\circ} \mathrm{C}$ (maximal survival at $\sim-80^{\circ} \mathrm{C}$ ) respectively. These two approaches to the cryopreservation of embryos have therefore come to be known as 'rapid' and 'slow' freezing methods, respectively, and are generally considered equally efficacious (Rall et al., 1984; Rall \& Polge, 1984). However, reports of studies using hamster oocytes (Quinn et al., 1982; Critser et al., 1986) or early cleavage-stage mouse (Quinn \& Kerin, 1986) and human (Trounson \& Mohr, 1983) embryos have indicated that terminating slow cooling at $-40^{\circ} \mathrm{C}$ with rapid thawing (rapid method) results in lower survival than cooling to $-80^{\circ} \mathrm{C}$ with slow thawing (slow method).

The existence of an interaction between the temperature at which slow cooling is terminated and the thawing rate observed in mammalian embryos is probably representative of differences in degrees of dehydration (Rall et al., 1984; Rall \& Poldge, 1984) and as such will be affected by blastomere water permeability, surface area/volume ratio, and the activation energy of water permeability (Leibo, 1977, 1980; Mazur et al., 1984). Surface area has been shown to increase with embryo development (Calarco \& Epstein, 1973; Burgos et al., 1976; Eager et al., 1976). Water permeability and the activation energy for water permeability have been shown not to differ between unfertilized and fertilized mouse ova (Leibo, 1980) although glycerol permeability increases and its associated activation energy decreases with fertilization in the mouse (Jackowski et al., 1980) and with subsequent development (Mazur et al., 1976). Changes in water permeability and/or its activation energy may also occur amongst embryos at later developmental stages. Collectively, such changes might explain differences among embryo stages within the temperature 
at which slow cooling is terminated by thaw-rate interaction. The results of the present experiments are expressed primarily in terms of development to the blastocyst stage based on the total number of embryos frozen rather than recovered. Due to the high recovery rates of unfrozen embryos in Exp. 1, we believe that, at least in general, embryos that are not recovered represent embryos which have undergone extensive damage and are no longer recognizable. Therefore, expressing data on the basis of the number of embryos frozen represents a conservative estimate of survival.

The present results, in part, are generally consistent with early reports examining the survival of frozen-thawed 2-cell mouse embryos. Nakagata \& Toyoda (1980) reported relatively high cryosurvival rates of embryos ( $\sim 80 \%$, based on total number of embryos frozen) after termination of slow cooling at $-70^{\circ} \mathrm{C}$ with subsequent slow $\left(6-10^{\circ} \mathrm{C} / \mathrm{min}\right)$ thawing. Shelton (1982) reported relatively low cryosurvival when slow cooling was terminated at $-40^{\circ} \mathrm{C}$ with subsequent rapid thawing $(27 \%)$ but somewhat higher survival rates $(37 \%)$ when slow cooling was terminated at $-30^{\circ} \mathrm{C}$ and thawing was rapid.

The termination of slow cooling at temperatures higher than $-32^{\circ} \mathrm{C}$ in conjunction with rapid warming was not studied in the present experiments. Such work may reveal a procedure which will result in still higher rates of cryosurvival. All experiments conducted here utilized 1.5 M-DMSO. Previous reports (Kasai et al., 1981; Miyamoto \& Ishibashi, 1981; Seidel et al., 1983; Farrand et al., 1985) have suggested that 3- and/or 4-way interactions may exist among cryoprotectant type, cryoprotectant concentration, temperature at which slow cooling is terminated and thaw rate. The results of these experiments and previous reports using morula- and blastocyst-stage cow embryos (Seidel et al., 1983; Farrand et al., 1985) would suggest the addition of developmental stage as a possible fourth or fifth term in these interactions. Further examination of these multiway interactions may provide additional insight into improving embryo cryosurvival rates.

This reseach was supported by the Mayo Foundation. We thank Dr Peter Mazur for critical reading of the manuscript and suggestions; Mr Glenn Augustine for execution of the computer programs for the statistical analysis; and Ms Sharon Jones and Ms JoAnn Rogers for preparation of the manuscript. Support for preparation of this manuscript was provided, in part, by the Methodist Center for Reproduction and Transplantation Immunology, Methodist Hospital, Indianapolis, IN.

\section{References}

Bavister, B.D., Leibfried, M.L. \& Lieberman, G. (1983) Development of preimplantation embryos of the golden hamster in a defined culture medium. Biol. Reprod. 28, 235-247.

Bowman, P.\& McLaren, A. (1970a) Viability and growth of mouse embryos after in vitro culture and fusion. $J$. Embryol. exp. Morph. 23, 693-704.

Bowman, P. \& McLaren, A. (1970b) Cleavage rate of mouse embryos in vivo and in vitro. J. Embryol. exp. Morphol. 24, 203-207.

Burgos, M.H., Segal, S.J. \& Passantino, T. (1976) Surface changes of the rat embryo before implantation. Fert. Steril. 27, 1085-1094.

Calarco, P.G. \& Epstein, C.J. (1973) Cell surface changes during preimplantation development in the mouse. Devl Biol. 32, 208-213.

Critser, J.K., Arneson, B.W., Aaker, D.V. \& Ball, G.D. (1986) Cryopreservation of hamster oocytes: effects of vitrification or freezing on human sperm penetration of zona-free hamster oocytes. Fert. Steril. 46, 277-284.
Eager, D.D., Johnson, M.H. \& Thurley, K.W. (1976) Ultrastructural studies on the surface membrane of the mouse eggs. J. Cell Sci. 22, 345-353.

Farrand, G.D., Elsden, R.P. \& Seidel, G.E., Jr (1985) Effect of slow cooling end point temperature on survival of frozen bovine embryos. J. Anim. Sci. 61, $460-465$.

Hahn, J. \& Schneider, U. (1982) Embryo transfer in laboratory animals as a tool in reproductive research. Expl Biol. Med. 7, 170-176.

Hoppe, P.C. \& Coman, D.R. (1983) Reduced survival in utero transferred mouse blastocysts compared with morulase. Gamete Res. 7, 161-167.

Jackowski, S.C., Leibo, S.P. \& Mazur, P. (1980) Glycerol permeabilities of fertilized and unfertilized mouse ova. J. exp. Zool. 212, 329-341.

Kasai, J., Niwa, K. \& Iritani, A. (1981) Effects of various cryoprotective agents on the survival of unfrozen and frozen mouse embryos. J. Reprod. Fert. 63, $175-180$. 
Leibo, S.P. (1977) Fundamental cryobiology of mouse ova and embryos. In The Freezing of Mammalian Embryos (Ciba Fdn Symp No. 52), pp. 69-96. Eds K. Elliott \& J. Whelan. Elsevier, Amsterdam.

Leibo, S.P. (1980) Water permeability and its activation energy of fertilized and unfertilized mouse ova. $J$. Membrane Biol. 53, 179-188.

Leibo, S.P. (1986) Cryobiology: preservation of mammalian embryos. Basic Life Sciences 37, 251-272.

Leibo, S.P. \& Mazur, P. (1978) Methods for the preservation of mammalian embryos by freezing. In Methods in Mammalian Reproduction, pp. 179-201. Ed. J. C. Daniel, Jr. Academic Press, New York.

Massip, A., Van der Zwalmen, P. \& Leroy, F. (1984a) Effect of stage of development on survival of mouse embryos frozen-thawed rapidly. Cryobiology 21, 574-577.

Massip, A., Van der Zwalmen, P., Puissant, F., Camus, M. \& Leroy F. (1984b) Effects of in-vitro fertilization, culture, freezing and transfer on the ability of mouse embryos to implant and survive. J. Reprod. Fert. 71, $199-204$.

Maurer, R.R. (1976) Storage of mammalian oocytes and embryos: a review. Can. J. Anim. Sci. 56, 131-145.

Mazur, P., Rigopoulas, N., Jackowski, S.C. \& Leibo, S.P. (1976) Preliminary estimates of the permeability of mouse ova and early embryos to glycerol. Biophys. $J$. 16, 232, Abstr.

Mazur, P., Rall, W.F. \& Leibo, S.P. (1984) Kinetics of water loss and the likelihood of intracellular freezing in mouse ova: influence of the method of calculating the temperature dependence of water permeability. Cell Biophysics 6, 197-213.

Merry, D.A., Allen, R.L., Krag, K. \& Wright, R.W., Jr (1983) Sucrose dilution of frozen mouse embryos: interaction of glycerol and sucrose concentrations. Theriogeneology 20, 325-332.

Miyamoto, H. \& Ishibashi, T. (1981) Survival of mouse embryos after freezing and thawing in the presence of erythritol. J. exp. Zool. 216, 337-340.

Nakagata, N. \& Toyoda, Y. (1980) Normal young after transfer of frozen-thawed 2-cell mouse embryos obtained by fertilization in vitro. Jpn. J. Zootech. Sci. 51, 740-744.

Polge, C. \& Willadsen, S.M. (1978) Freezing eggs and embryos of farm animals. Cryobiology 15, 370-373.

Quinn, P. \& Kerin, J.F.P. (1986) Experience with the cryopreservation of human embryos using the mouse as a model to establish successful techniques. $J$. In Vitro Fertilization and Embryo Transfer 3, 40-45.

Quinn, P., Barros, C. \& Whittingham, D.G. (1982) Preservation of hamster oocytes to assay the fertilizing capacity of human spermatozoa. J. Reprod. Fert. 66, 161-168.

Rall, W.F. \& Polge, C. (1984) Effect of warming rate on mouse embryos frozen and thawed in glycerol. $J$. Reprod. Fert. 70, 285-292.

Rall, W.F., Reid, D.S. \& Polge, C. (1984) Analysis of slow-warming injury of mouse embryos by cryomicroscopical and physicochemical methods. Cryobiology 21, 106-121.

Renard, J.P. \& Babinet C. (1984) High survival of mouse embryos after rapid freezing and thawing inside plastic straws with 1-2 propanediol as cryoprotectant. J. exp. Zool. 230, 443-448.
Schneider, U. (1986) Cryobiological principles of embryo freezing. J. In Vitro Fert. Embryo Transfer 3, 3-9.

Schneider, U. \& Maurer, R.R. (1983) Factors affecting survival of frozen-thawed mouse embryos. Biol. Reprod. 29, 121-128.

Schneider, U. \& Mazur, P. (1984) Osmotic consequences of cryoprotectant permeability and its relation to the survival of frozen-thawed embryos. Theriogenology 21, 68-79.

Seidel, G.E., Jr \& Seidel, S.M. (1981) The embryo transfer industry. In New Technologies in Animal Breeding, pp. 41-77. Eds B. G. Brackett, G. E. Seidel, Jr \& S. M. Seidel. Academic Press, New York.

Seidel, G.E., Jr, Elsden, R.D., Takeda, T. \& Farrand, G.D. (1983) Field trial with cryopreserved bovine embryos. In Fertilization of the Human Egg In Vitro, pp. 343-352. Eds H. M. Beier \& H. R. Lindner. Springer-Verlag, Berlin.

Shelton, K. (1982) The successful cryopreservation of in vitro fertilized mouse embryos. Cryo-Letters 2, 305-310.

Snedecor, G.W. \& Cochran, W.G. (1982) In Statistical Methods, 7th edn, p. 290. Iowa State University Press, Ames.

Spector, P.C., Goodnight, J.H., Sall, J.P. \& Sarle, W.S. (1985) The GLM procedure. In SAS User's Guide: Statistics, Version 5 Edition, pp.433-507. SAS Institute, Cary.

Steel, R.G.D. \& Torrie, J.H. (1960) Principles and Procedures of Statistics, p. 99, McGraw-Hill, New York.

Trounson, A.O. \& Mohr, L. (1983) Human pregnancy following cryopreservation, thawing and transfer of an eight-cell embryo. Nature, Lond. 305, 707-709.

Whittingham, D.G. (1974) Embryo banks in the future of developmental genetics. Genetics, Princeton 78, $395-402$.

Whittingham, D.G. (1975) Low temperature storage of mammalian embryos. In Basic Aspects of Freeze Preservation of Mouse Straws, pp. 45-55. Ed. O. Muhlbock. Gustav-Fischer Verlag, Stuttgart.

Whittingham, D.G. \& Wales, R.G. (1969) Storage of twocell mouse embryos in vitro. Aust. J. biol. Sci. 22, 1065-1068.

Whittingham, D.G. \& Whitten, W.K. (1974) Long-term storage and aerial transport of frozen mouse embryos. J. Reprod. Fert. 36, 433-435.

Whittingham, D.G., Leibo, S.P. \& Mazur, P. (1972) Survival of mouse embryos frozen to $-196^{\circ} \mathrm{C}$ and $-269^{\circ} \mathrm{C}$. Science, N.Y. 178, $411-414$.

Whittingham, D.G., Wood, M., Farrant, J., Lee, H. \& Halsey, J.A. (1979) Survival of frozen mouse embryos after rapid thawing from $-196^{\circ} \mathrm{C} . J$. Reprod. Fert. 56, 11-21.

Willadsen, S.M. (1977) Factors affecting the survival of sheep embryos during deep freezing and thawing. In Freezing of Mammalian Embryos (Ciba Fdn Symp. No. 52), pp. 175-189. Eds K. Elliott \& J. Whelan. Elsevier, Amsterdam.

Willadsen, S.M., Polge, C. \& Rowson, L.E.A. (1978) In vitro storage of cattle embryos. In Control of Reproduction in the Cow, pp. 427-437. Ed. J. Sreenan. European Economic Community, Luxembourg.

Received 30 January 1987 